\title{
Evaluation of motorcycle accidents admitted to the emergency service and the relationship of alcohol with other demographic properties in motorcycle accidents
}

\author{
Ayşen Dikici Ersana,* (D), Zeynep Karakayab (D), Fatih Esat Topalb (D), Umut Payzab (D), Pınar Yeşim \\ Akyolb (D) \\ aDepartment of Emergency Medicine, Akhisar Mustafa Kirazoğlu State Hospital, Manisa, Turkey, \\ bDepartment of Emergency Medicine, Katip Çelebi University, Atatürk Training and Research Hospital İzmir, Turkey
}

\section{A R T I C LE I N F O}

\section{Article history:}

Received 28 August 2019

Received in revised form 01 January 2020

Accepted 11 February 2020

\section{Keywords:}

Emergency department

Motorcycle accident

Alcohol

\begin{abstract}
A B S T RACT
Objective: Motorcycle accidents progress with higher mortality than other accidents. There can be many different factors in the emergence of accidents. The aim of this study is to evaluate the effects of alcohol and other demographic characteristics on motorcycle accidents. Materials and Methods: Patients who were admitted to the emergency department after motorcycle accidents between 01.10.2013-01.10.2014 were evaluated retrospectively. Features such as blood ethanol levels, age, sex, time of admission to the emergency department (hour, day, month and season), weather conditions, mortality, hospitalization and operation necessity and the loss of labor were discussed. Findings: 241 patients were included in the study where $99.2 \%$ of the patients were male and the mean age was $27,04 \pm 10,86$. Most of the accidents are found to have occurred in the evening $(49.8 \%)$, in autumn $(31 \%)$ and sunny/outdoor conditions $(51 \%)$ with good visibility. It was determined that 3 patients died due to head trauma, 142 patients were evaluated and discharged from the emergency department and 41 patients were determined to have labor loss longer than 1 month. Conclusion: In motorcycle accidents, mostly young males have been affected. Most of the alcoholic patients $(50 \%)$ consist of young patients aged between 18-40 years. It has been revealed that head trauma is an important cause of mortality and morbidity in such accidents.
\end{abstract}

(C) 2020. Turkish Journal Park Academic. All rights reserved.

\section{Introduction}

In developing countries where highways are used more frequently, traffic accidents remain a major problem. Despite the advances in vehicle and road technology, improved safety equipment, and increased training and warning activities, loss of life, disability, loss of labor and economic losses continue to increase. Not only more than one million people die every year in traffic accidents, but also 20 to 50 million injuries occur. $90 \%$ of these accidents occur in developing countries. Although trauma management has improved in developed countries, motor vehicle accidents, especially under 44 , are still the leading cause of death in the world (1). There may be an increase in traumatic injuries (traffic accidents, falls, violence incidents) due to psychological and mental health problems associated with alcohol use. These traumas, which may be related to alcohol use, constitute $23 \%$ of emergency department admissions $(2,3)$. The use of alcohol in drivers is regulated by rules in many countries due to the fact that the traffic accident is one of the most dangerous consequences of alcohol use. While some of the drivers prefer motorcycles for economic reasons and its ease of use, as well as traffic density and parking problems in big cities, some others prefer motorcycles to facilitate and accelerate the works and save

\footnotetext{
* Corresponding author. 
time. With the increase in the use of motorcycles, we also encounter accidents more often. In this study, demographic characteristics of patients admitted to the emergency department after motorcycle accidents were discussed.

\section{Materials and methods}

\subsection{The study plan}

This study is a retrospective descriptive study. Permission for the study was obtained from İzmir Katip Çelebi University Atatürk Training and Research Hospital Ethics Committee. The study was planned in Izmir Katip Çelebi University Atatürk Training and Research Hospital Emergency Department between 01.10.2013 and 01.10.2014.

Those who ride on motorcycles, accidents involving motorcycle collisions with another motor or non-motorized vehicle are included in the study whereas pedestrians who were injured by a motorcycle or bicycle were not included in the study. The patients, who were not known to have motorcycle injuries, who were not traumatized, who lacked information in their files and who left the hospital voluntarily without any physical examinations were not included in the study. The data on the ages, genders, time of admission to the Emergency Department (hour, day, month) were classified. The blood ethanol levels, whether or not consultations were made, diagnoses in hospitalization, discharge and death and the data on the mechanisms of accidents related data were evaluated.

Parameters took places such as the presence of personal protective measures and driver's license, abnormal physical examination findings, Glasgow Coma Scale (GCS) score, radiological findings, final diagnoses, consultation rates, hospitalization periods and hospital stay. Data obtained were computerized from the forms.

\subsection{Statistical Analyses}

Data were recorded in Microsoft Office 2007 Excel and SPSS (Statistical Package of Social Sciences) 20 for Windows statistical programs.

Descriptive statistical methods (percentage, mean and standard deviation) were used to evaluate the study data. $\mathrm{p}$ $<0.05$ was considered statistically significant. $\mathrm{P}<0.05$ was considered statistically significant.

\section{Findings}

241 patients who met the criteria were included in our study (Table 1). While 239 (99.2\%) of the cases were male and 2 $(0.8 \%)$ were female, and the mean age was $27.04 \pm 10.865$. 170 patients $(70.5 \%)$ were in the $18-40$ age range.
Table 1. General characteristics of patients

\begin{tabular}{|c|c|c|c|}
\hline & & $\mathrm{n}$ & $\%$ \\
\hline \multirow[t]{3}{*}{ Age } & $<18$ & 34 & 14.1 \\
\hline & $18-40$ & 171 & 71.0 \\
\hline & $>40$ & 36 & 14.9 \\
\hline \multirow[t]{2}{*}{ Gender } & Female & 2 & .8 \\
\hline & Male & 239 & 99.2 \\
\hline \multirow[t]{3}{*}{ Admission Time } & 08:00-16:00 & 84 & 34.9 \\
\hline & 16:01-00:00 & 120 & 49.8 \\
\hline & 00:01-07-59 & 37 & 15.4 \\
\hline \multirow[t]{7}{*}{ Day } & Monday & 33 & 13.7 \\
\hline & Tuesday & 33 & 13.7 \\
\hline & Wednesday & 36 & 14.9 \\
\hline & Thursday & 33 & 13.7 \\
\hline & Friday & 42 & 17.4 \\
\hline & Saturday & 30 & 12.4 \\
\hline & Sunday & 34 & 14.1 \\
\hline \multirow[t]{2}{*}{ Day } & Weekdays & 177 & 73.4 \\
\hline & Weekend & 64 & 26.6 \\
\hline \multirow[t]{3}{*}{ Weather Condition } & Sunny & 123 & 51.0 \\
\hline & Cloudy & 77 & 32.0 \\
\hline & Rainy & 41 & 17.0 \\
\hline \multirow[t]{12}{*}{ Admission Month } & January & 14 & 5.8 \\
\hline & February & 17 & 7.1 \\
\hline & March & 21 & 8.7 \\
\hline & April & 20 & 8.3 \\
\hline & May & 22 & 9.1 \\
\hline & June & 19 & 7.9 \\
\hline & July & 15 & 6.2 \\
\hline & August & 27 & 11.2 \\
\hline & September & 30 & 12.4 \\
\hline & October & 16 & 6.6 \\
\hline & November & 29 & 12.0 \\
\hline & December & 11 & 4.6 \\
\hline \multirow[t]{4}{*}{ Season } & Spring & 63 & 26.1 \\
\hline & Summer & 61 & 25.3 \\
\hline & Autumn & 75 & 31.1 \\
\hline & Winter & 42 & 17.4 \\
\hline \multirow[t]{2}{*}{ Ethanol } & Less than 50 & 217 & 90.0 \\
\hline & 50 and more & 24 & 10.0 \\
\hline \multirow[t]{2}{*}{ Consultation } & Yes & 112 & 46.5 \\
\hline & No & 129 & 53.5 \\
\hline \multirow[t]{4}{*}{$\begin{array}{l}\text { Hospitalization/ } \\
\text { Discharge }\end{array}$} & Discharged & 142 & 58.9 \\
\hline & Hospitalization & 58 & 24.1 \\
\hline & $\begin{array}{l}\text { Leave the clinic without } \\
\text { permission / discharged } \\
\text { with his own request }\end{array}$ & 40 & 16.6 \\
\hline & Ex & 1 & .4 \\
\hline \multirow{2}{*}{$\begin{array}{l}\text { Total Hospitalization + } \\
\text { Report Duration }\end{array}$} & No & 139 & 57.7 \\
\hline & 7 days and fewer & 28 & 11.6 \\
\hline
\end{tabular}




8-30 days $\quad 33 \quad 13.7$

More than 30 days

17.0
Evaluation of the admission times to the emergency department of patients injured directly showed that 84 (34.9\%) of the patients were admitted during working hours (between 08: 00-16: 00), 120 (49.8\%) in the evening (16: 0100: 00), and 37 (15.4\%) during the night (00: 01-07: 59). Most of the accidents were found to have happened in September $(12.4 \%)$ and in November (12\%) and the fewest were in December (\%4.6), while 123 (51\%) of the accidents occurred in normal weather/road conditions, 77 (32\%) occurred in cloudy/overcast weather conditions and 41 (17\%) occurred in rainy weather conditions.

Evaluations of the injuries of the patients showed 155 patients $(64.3 \%)$ had isolated limb injuries, 33 patients $(13.7 \%)$ had a head injury, 32 patients $(13.3 \%)$ had facial injuries and 3 patients $(1.2 \%)$ did not have any injuries. Multiple body traumas were found in 79 patients $(32.8 \%)$ (Table 2).

Table 2. Distribution of traumas of patients according to body regions

\begin{tabular}{lll}
\hline Zone of Injury & (n) & $\%$ \\
\hline 1-No Injury & 3 & 1.2 \\
2-Head & 33 & 13.7 \\
3-Face & 32 & 13.3 \\
4-Spinal & 16 & 6.6 \\
5-Thorax & 8 & 3.3 \\
6-Abdomen & 11 & 4.6 \\
7-Pelvis & 6 & 2.5 \\
8-Extremity & 155 & 64.3 \\
\hline
\end{tabular}

It was determined that 142 patients (58.9\%) were discharged from the emergency department, $40 \%$ (16.6\%) of the patients left the emergency room without permission or refused treatment, 58 patients $(24.1 \%)$ were admitted to the relevant departments, 1 patient $(0.4 \%)$ died in the emergency department and 2 patients died due to cranial trauma in the intensive care unit

It was found that $139(57.7 \%)$ patients were able to return to their working life the following day after examinations and treatments performed in the emergency department, and 28 $(11.6 \%)$ were able to work in less than 1 week,33 $(\% 13,7)$ had a medical report to rest and recuperate for 1 week to 30 days, and that $41(17 \%)$ had to interrupt their working life for more than 1 month due to health problems.

\section{Discussion}

The mortality and morbidity of the rider and/or passenger are higher than those of other vehicles in the case of traffic accidents involving vehicles which are more unprotected such as motorcycles and bicycles. Patients who are admitted to the emergency department after motorcycle accidents should be evaluated in terms of death and disability as soon as possible with a multidisciplinary trauma approach.

Being a male is an important factor among the effects which determine the occurrence of the accident according to the WHO (4). In accordance with other studies conducted in our country and abroad, most of the patients we evaluated in our study $(99.2 \%)$ were male. The male patient ratio was determined as $88.5 \%$ by Asirdizer et al. (5) and $94.7 \%$ by A. Moskal et al. (6).

The mean age of the patients we evaluated in our study was calculated as $27.04 \pm 10.865$ (14-61). The majority of the patient age group was in the 18-40 age range, in a total of 170 $(70.5 \%)$ patients and this situation is consistent with other studies in the literature. In a study conducted in Izmir (7), motorcycle accidents were found to have occurred most frequently in the 24.5-39.4 age group, and in another study by Coben et al. (8), $62 \%$ of those injured in motorcycle accidents were reported to have been older than 30 years of age. When we examine the age of motorcycle users according to their blood ethanol levels, the average age of our patients had ethanol levels $>50 \mathrm{mg} / \mathrm{dl}$ is 35.33. In a similar study conducted by Hang-Tsungliu et al. (9), the mean age of patients with ethanol levels was above $50 \mathrm{mg} / \mathrm{dl}$ was found as 39.2 years. The fact that the minimum age for legal motorcycle use is 17 (10), motorcycle use is common among young people, and that the use of motorcycles is not preferred due to health problems in advancing age (such as slow reflexes, balancing problems, and vision problems) may have caused the rise of the most intense patient ages to be between 18-40.

When we evaluated our study according to admission hours, 120 (49.8\%) out of 241 admissions to the emergency department were between 16: 01-00: 00 hours and the minimum number of admissions was found to be 37 (15.4\%) between 00:01-07:59.In a study conducted by Asirdizer et al. (5), when the admission time of motorcycle and bicycle accidents were examined, it was found that $65.4 \%$ of the admissions emerged between 12.01 and 20:00 and these values were close to the data in our study. When we examined our study according to the blood ethanol levels of the patients who were admitted, it was determined that the patients with alcohol admitted intensively between 00: 01 and 7: 59. Liu et al. (9) found that patients with alcohol who admitted to the emergency department after motorcycle accidents had applied to the emergency department generally between 17: 00 and 07: 00. In the same study, it was observed that patients without alcohol were admitted to the hospital during the day (07: 00-17: 00). Admissions mainly between 16: 0100: 00 may be due to the fact that these hours include when people are not working or the hours they spare the time for themselves, outside of rush hours and peak traffic hours. When we examine the admissions according to the level of 
ethanol in the blood, the increase in alcohol consumption after the end of working hours and the closure hours of entertainment venues where alcohol consumption is high, such as cafes and bars are within our time range and maybe the reasons for this time interval shifting to 00: 01-07.

Despite the fact that $41 \%$ of injuries related to motorcycle accidents are reported to occur at the weekend (8), in another study (6) $25.6 \%$ of motorcycle accidents were found to occur at the weekend. In our study, this rate was found to be $26.55 \%$ and most of the injuries related to motorcycle accidents were determined to have occurred on Wednesdays and Fridays, however, no statistical significance was found between the days of the week and the occurrence of accidents $(\mathrm{p}>0.05)$.

While in our study most of the accidents were found to have occurred in autumn months (31.1\%), in a similar study conducted by Moskal et al. in France (6), the most frequent accidents were found to have occurred in the summer months (39.4\%)and the second most common accidents were found in autumn $(\% 37,5)$. A significant difference between the number of patients in our study and the number of patients in the study performed by Moskal et al could have caused a difference between the two studies (in our study 241 patients, Moskal et al. 181228 patients).

In a study evaluating fatal motorcycle accidents and vehicle accidents (11), $7.6 \%$ of motorcycle riders with alcohol and $10.4 \%$ of motorcycle riders without alcohol were found to have had accidents in weather conditions in which the field of vision is bad. In our study, it was found that $8.4 \%$ of patients with alcohol and $18 \%$ of patients without alcohol had an accident on days when the weather was rainy.

Of the 241 patients included in our study, 24 (10\%) of them had blood ethanol levels which are above $50 \mathrm{mg} / \mathrm{dl}$. When the studies examining motorcycle accidents similar to the literature are considered, it was determined in a study conducted by Kasantikul et al. in Thailand (12) that $36.3 \%$ of 99.4\% patients whose blood ethanol levels could be measured were found to have had alcohol while in the study conducted in the province of Bursa in our country examining traffic accidents $5.5 \%$ of accidents included in the study was a motorcycle accident) by Durak et al, 6.9\% of the casualties were found to have had alcohol in their system. The difference in the amount of alcohol consumption between regions and the change in the intensity of motorcycle use by regions may have caused a difference between the study conducted in Thailand and other studies conducted in our country.

In our study, 79 patients (32.8\%) were found to have multiple body traumas. It was determined that 155 patients $(64.3 \%)$ had limb injuries. When the literature on the subject is examined, it was seen in the previous studies that motorcycle riders were generally injured in more than one body area $(14,15)$, and the most common injuries were observed in the lower extremity $(14,16,17,18)$. The fact that only helmets and protective goggles are listed on the list of compulsory equipment for motorcycles and that other equipment that is protective of the body are not legally obligated, ensures that people do not show the necessary importance and priority to these clothes and since the motorcycle is overturned to the right or left at the time of the accident due to the vehicle structure, as a result of this overturning, one side of the driver's body may remain under the motorcycle. Therefore, this could be the reason for extremity injuries in the majority of the accidents.

Cranial injuries are the leading cause of death due to motorcycle accidents as determined in the literature $(16,19)$. In our study, 3 patients died due to head trauma in accordance with the literature. It was stated that one of these patients had died in the emergency department and the other 2 patients had died in the intensive care unit due to cranial trauma.

It was determined that 142 patients (58.9\%) included in our study were discharged from the emergency department and 58 patients $(24.1 \%)$ were admitted to related departments. It was found that 40 patients $(69 \%)$ were operated on, 7 of whom under emergency conditions, and 18 patients $(31 \%)$ were hospitalized and had medical treatment. In the study which Durak et al. (13) evaluated the traffic accidents in Bursa province in our country, it was found that $43 \%$ of the casualties were discharged from the emergency department, $37 \%$ were hospitalized, and $17.4 \%$ of patients were referred to another center for further examination and treatment. When the patients whose blood ethanol levels are above 50 $\mathrm{mg} / \mathrm{dl}$ are examined following their examination and interventions in the emergency department, it was determined that 9 patients (37.5\%), were hospitalized for treatment and/or operation and 7 patients (29.2\%) were found to be discharged from the emergency department. In our study, no statistically significant difference was found between alcohol use, admission and discharge status ( $\mathrm{p}>$ 0.05). According to a study by Kasantikul et al. (12), it was found that $45 \%$ of patients with alcohol required hospitalization or lost their lives and it was determined that one-fourth of the patients needed hospitalization or lost their lives.

Finally, it was determined that $28(11.6 \%)$ of our patients evaluated in our study were able to return to their normal life following hospitalization and resting for up to 1 week, 33 $(13.7 \%)$ patients were required to be hospitalized and rested between 1 week and 30 days, 41 (17\%) were treated for longer than 1 month and had to have a break in their working life. When the literature related to similar situations is examined, in a study, carried out by Asirdizer et al. (5), examining the cases who were injured in the motorcycle or bicycle accidents, it was found that 32 patients $(35.6 \%)$ received outpatient treatment, 40 (44.4\%) patients were hospitalized for 1 to 10 days and 18 patients (20\%) were hospitalized for 10 days. When we examined our study according to the blood ethanol levels of the patients admitted, it was determined that 2 out of 24 patients (8.3\%)whose blood ethanol level was found above $50 \mathrm{mg} / \mathrm{dl}$ were able to start work after 1 week or less than one-week hospitalization and resting, $3(12.5 \%)$ of them required hospitalization and resting between 1 week and 30 days, 5 patients (20.8\%) were treated more for than 1 month and should have a break in their working life and 14 patients were found to have 
returned to their normal life after being discharged from the emergency department. Liu et al. (9), in the study in which they examined alcohol-related hospitalization, found that the mean duration of hospitalization of inpatients with alcohol in the hospital and intensive care units was 12 days and 13.2 days in patients without alcohol, and no correlation was found between the day of hospitalization and being with or without alcohol.

\section{Limitations}

All cases in the study dates could not be included since our study was retrospective and the data in the patient files were insufficient, furthermore, the fact that our study was singlecentered and that the emergency department was the $3 \mathrm{rd}$ step emergency service in the urban area made our study inadequate in terms of generalization. No information was obtained about the presence of protective equipment of patients or the way the accidents occurred. Demographic characteristics of motorcycle accidents in our country can be better demonstrated in a multi-centered study in which the prospective data can be compiled completely, including rural and urban areas where different levels of emergency services are included.

\section{Conclusion}

According to the data obtained from our study, it was found that motorcycle accidents due to alcohol occurred mostly in age groups over the age of 40 and during the night (between 00: 00-07: 59), in contrast to the predictions in better weather conditions, and most of the injuries were in the extremities. In addition, no statistically significant difference was determined in demographic data (in terms of the day, month, seasons of admission time, distribution of available trauma areas, hospitalization/discharge status and resting periods after the accident) except the blood ethanol level, distribution of the patients' ages and the hours of admission.

\section{References}

1. AmericanCollege of Surgeons Committee on Trauma. Advanced Trauma Life Support for Doctors (ATLS), Student course Manual Tenth Edition, Chicago: The American College of Surgeons, 2018

2. Sayal A, Aydın A, Demirkan K, Işımer A. Alkol kullanımı ve suç oranı Gülhane Tıp Dergisi 2005;47(1) : 14-17.

3. Fabbri A, Marchesini G, Morselli-Labate AM, et al. Positive blood alcohol concentration and road accidents. A prospective study in an Italian emergency department Emerg Med J 2002;19: 210-14
4. Peden $M$ et al.; Eds., 'The World Report on Road Traffic Injury Prevention' Summary. Gneva, World Health Organization Library Cataloguing; 200

5. Aşırdizer M., Yavuz S, Zeyfeoğlu Y ve ark. 2003-2009 Yılları Arasında Celal Bayar Üniversitesi Tıp Fakültesi Adli Tıp Anabilim Dalı Polikliniği'ne Başvurmuş Motosiklet/Motorlu Bisiklet Veya Bisiklet Kazalarında Yaralanmıș Olguların Değerlendirilmesi. Adli Tıp Dergisi 2009; 23(3): 17-26

6. Moskal A, Martin JL, Laumon B. Risk factors for injury accidents among moped and motorcycleriders. Accident Analysis and Prevention 49 (2012) 5- 11

7. Topçuoğlu M, Güler H, Koçak A, Aktaş EÖ, Şenol E, Ersel M, Boydak B, Kaya A. Motosiklet ve bisiklet kazaları sebebiyle Ege Üniversitesi Tıp Fakültesi acil servisine başvuran olguların özellikleri. 6. Anadolu Adli Bilimler Kongresi Sözel ve Poster Bildiriler Kitabı (Eds: Aşırdizer M, Yavuz MS) 'nda. Manisa: Celal Bayar Üniversitesi Matbaası. 2007:132-6

8. Coben JH, Steiner CA, Owens P. Motorcycle-related hospitalizations in the United States, 2001. Am J PrevMed. 2004; 27(5): 355-62.

9. Liu HT, Liang CC, Rau CS, Hsu SY andHsieh CH. Alcohol-related hospitalizations of adultmotorcycleriders. World Journal of $\begin{array}{lll}\text { Emergency } & \text { Surgery }\end{array}$ http://www.wjes.org/content/10/1/2

10. Sürücü Belgesi İșlemleri - Sürücü Belgesi Alacaklarda Yaș Șartı. Erişim adresi: http://www.asbis.gov.tr/surucu-belgesiislemleri.asp

11. Huang WS, Lai CH. Survival risk factors for fatal injured car and motorcycle drivers in single alcohol-related and alcoholunrelated vehicle crashes. Journal of Safety Research 42 (2011) 93-99

12. Kasantikul V, Ouellet JV, Smith $T$, Sirathranont J, Panichabhongse $\mathrm{V}$. The role of alcohol in Thailand motorcycle crashes. Accident Analysis and Prevention 37 (2005) 357-366

13. Durak D, Fedakar R, Türkmen N, Akgöz S, Baduroğlu E. Road traffic collisions in Bursa, Turkey, during 2003, 2004 and 2005. Injury, Int. J. Care Injured (2008) 39, 547-553

14. Bachulis, B.L., Sangster,W., Gorrell, G.W., et al., 1988. Patterns of injury in helmeted and nonhelmeted motorcyclists. Am. J. Surg. 155, 708-711.

15. Rogers, C.D., Pagliarello, G., McLellan, B.A., Nelson, W.R., 1991. Mechanism of injury influences thepattern of injuries sustained by patients involved in vehiculartrauma. Can. J. Surg. 34 (3), 283-286.

16. Kraus, J.F., McArther, D.L., Silberman, T.A., 1994a. Epidemiology of mildbrain injury. Semin. Neurol. 14, 1-7.

17. Peek, C., Braver, E.R., Shen, H., et al., 1994. Lower extremity injuries from motorcycle crashes: a commoncause of preventable injury. J. Trauma 37, 358-364.

18. Wladis, A., Boström, L., Nilsson, B., 2002. Injuries in 8927 patients admitted after motor-cyclecrashes in Sweden 19871994 inclusive. Eur. J. Surg. 168, 178-192.

19. Ankarath, S., Giannoudis, P.V., Barlow, I., Bellamy, M.C., Matthews, S.J., Smith, R.M., 2002. Injury patterns associated with mortality following motorcycle crashes. Injury 33, 473-477. 